\title{
Separation of Kaolinite from Ion-Adsorption Rare Earth Tailings in Southern China and Iron Removal Treatment
}

\author{
Yongqing Wang, Huayin Liang, Qibing Chang*, Xiaozhen Zhang, Jian'er Zhou \\ School of Materials Science and Engineering, Jingdezhen Ceramic Institute, Xianghu, \\ Jingdezhen, China \\ Email:wyq8248@126.com, 70808@qq.com, "changqb1258@hotmail.com, zhangxz05@126.com, \\ Ip0518@126.com
}

Received 9 December 2015; accepted 18 January 2016; published 21 January 2016

Copyright (C) 2016 by authors and Scientific Research Publishing Inc.

This work is licensed under the Creative Commons Attribution International License (CC BY). http://creativecommons.org/licenses/by/4.0/

(c) (i) Open Access

\begin{abstract}
Several hundred million tons of ion-adsorption rare earth tailings exist in Ganzhou, Southern China, which is a severe environmental hazard. To reduce and reutilize the tailing, kaolinite has been separated from the tailings by mechanical separation in laboratory scale and pilot scale. The results show that the tailing is mainly composed of fine kaolinite and coarse quart. Quartz and kaolinite can be separated by sieves, shaker, spiral chute or hydrocyclone, which has the similar results in laboratory scale and pilot scale. $30.2 \%$ of the tailings can be re-sourced and applied in ceramic industries. $41.7 \%$ of kaolinite can be obtained after sorting and iron removal by magnetic separator in pilot scale, which can be applied in ceramic industries according to the Chinese national standard (TC-3). The results give a progressive solution to re-source the tailings economically.
\end{abstract}

\section{Keywords}

Rare Earth Tailing, Kaolinite, Separation, Reutilize, Iron Removal

\section{Introduction}

Rare earth elements (REEs) have become vital and indispensable components of many high-tech products, devices and technologies. China's production of rare earth minerals has provided more than $90 \%$ of the world's supply since 2001 (Su, 2009; Chen, 2011) [1] [2]. However, what is left in China is million tons of tailings because rare earth ore deposits have relatively low REEs concentrations ranging from 10 to a few hundred parts

${ }^{*}$ Corresponding author. 
per million by weight (Yang, et al., 2013) [3]. Ion-adsorption rare earth reserves only distribute in seven provinces of southern China (Su, 2009; Wübbeke, 2013) [1] [4]. The ion-adsorption rare earth deposits were formed by chemical weathering decomposition and dissolution of granite and granite porphyry (containing relative high abundance of rare earth elements) and subsequent adsorption and enrichment on clay minerals during the migration and penetration process of rare earth mineral solutions. Unlike other rare earth minerals which are in solid state mineral phase and tend to be symbiotic or associated with the radioactive elements uranium and thorium, ion-adsorption rare earth minerals occur at a simple trivalent cationic state which is simply adsorbed onto clay sand and can be readily extracted by a simple leaching technique via anion-exchange process (Yang, et al., 2013) [3]. Hence, the tailings can be and must be re-sourced because there are 191 million tons of tailings just distributed in Ganzhou region (Jiangxi Province, Southern China).

Kaolinite and quartz are the main components of the tailings characterized by Mineral Liberation Analyzer. It is possible to separate of kaolinite from the tailings due to the differences of density and particle size of kaolinite and quartz. In the present work, several methods of mineral separation were applied to the tailings and a systemic separation of the tailing was proposed.

\section{Materials and Methods}

\subsection{Collection and Pre-Treatment of Tailings Samples}

The tailings were collected from the ores of ion-adsorption rare earths in Ganzhou, Southern China. Representative sample was made by following Chinese standard method of mixing (China Standard Specification, GB 2007. 1-87). No further grinding treatment was conducted in laboratory. The tailings were dried in oven at $100^{\circ} \mathrm{C}$ overnight, cooled naturally, and then be characterized.

The tailings was suspended in water (1:4 tailings to water ratio) and slurried by stirring with an impeller stirrer without adding any dispersant or adjusting the $\mathrm{pH}$ value.

\subsection{Characterization}

The bulk chemical element analysis in samples melted with lithium tetraborate was performed with an XRF spectrometer (Axios mAX PANalytical, Netherland).

The bulk mineral composition was performed with Mineral Liberation Analyzer (MLA 650, Czech Republic).

The particle size distribution of the tailings was measured by wet sieving method using $20 \mathrm{wt} \%$ suspensions.

The sieve size of the copper standard sieves were sequentially $0.8 \mathrm{~mm}, 0.4 \mathrm{~mm}, 0.25 \mathrm{~mm}, 0.12 \mathrm{~mm}, 0.075 \mathrm{~mm}$, and $0.043 \mathrm{~mm}$.

\subsection{Sorting Experiments in Laboratory Scale}

Sorting of tailing by shaker: $500 \mathrm{ml} 20 \mathrm{wt} \%$ tailings slurry was put into a shaker (6-S, China). The separation condition kept that: the stroke is $10 \mathrm{~mm}$; the frequency is $220 / \mathrm{min}$.

Sorting of tailing by settlement: $500 \mathrm{ml} 20 \mathrm{wt} \%$ tailings slurry was sieved by wet sieving. The $-0.043 \mathrm{~mm}$ fraction of tailings was further slurried in water (about $10 \mathrm{wt} \%$ solid) and then put into a cylinder (500 ml in volume). The slurry is stood undisturbed for $1 \mathrm{hr}$. The height of the slurry was separated according to Stoke equation of $5 \mu \mathrm{m}, 10 \mu \mathrm{m}$ and $20 \mu \mathrm{m}$.

Iron removal: $500 \mathrm{ml} 20 \mathrm{wt} \%$ tailings slurry was sieved by wet sieving. The $-0.043 \mathrm{~mm}$ fraction of tailings was put into a cycle type high gradient magnetic separator (SSS-I-145) (Chen, L., 2011, Svoboda, J., 2003) [5] [6]. The magnetic field intensity is in the range of $0.2 \mathrm{~T}-1.0 \mathrm{~T}$.

For the three processes above-mentioned, all the classified tailings were collected, and then dried in oven at $100^{\circ} \mathrm{C}$ overnight. The dried tailings were weight and characterized by XRF.

\subsection{Separation Experiments in Pilot Scale}

$200 \mathrm{~kg}$ tailings were suspended in water to form $20 \mathrm{wt} \%$ slurry. The flow chart of the separation of the slurry is shown in Figure 1. The slurry was firstly sieved by a high frequency vibrating sieve (GYX11-1210, sieve size is $0.4 \mathrm{~mm}$ ). The $-0.44 \mathrm{~mm}$ fraction of the slurry was delivered into a spiral chute (TGL 0610) by a high-pressure pump. The K4, K5 fraction of the slurry were separated by a hydrocyclone. The overflow was separated by the 


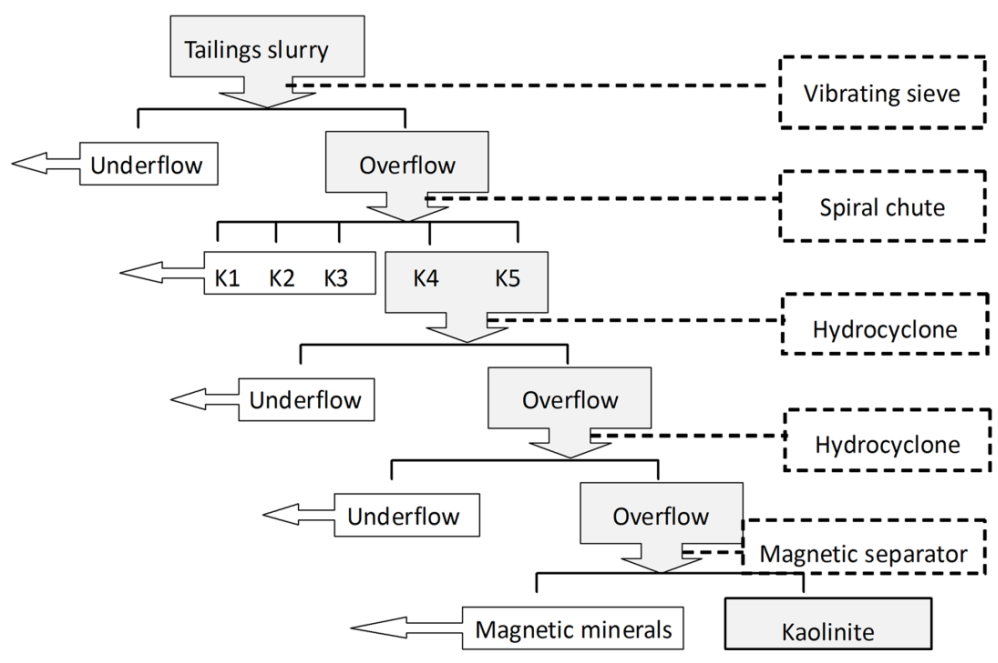

Figure 1. Flow chart of the tailings separation in pilot scale.

hydrocyclone secondly. Finally, the second overflow was put into wet dual band, high intensity, and high gradient magnetic separator (SSS-I-800). The magnetic field intensity is in the range of $0.6 \mathrm{~T}$.

For the processes above-mentioned, all the classified tailings were collected, and then dried in oven at $100^{\circ} \mathrm{C}$ overnight. The dried tailings were weight and characterized by XRF.

\section{Results and Discussions}

\subsection{Characterization of the Tailings}

\subsubsection{Chemical Composition of Tailings by MLA}

Table 1 shows the mineral composition of the tailings. As can be seen, kaolinite and Quartz is the major mineral of the tailings, which shares $91.98 \%$ of the tailings. It implies that the tailings can be re-utilized in ceramic application through the separation of kaolinite or quartz. The other silicates are feldspar, biotite, muscovite and amphibole. These silicates do not need the separation before the ceramic application because the contents are small and they also can be used as sintering aid in the calcinations of ceramic. The iron and titanium minerals include of titanomagnetite, limonite, pyrite, ilmenite, rutile, iron sphene and leucoxene, which shares about 1.77\% of the tailings. The iron and titanium minerals should be removed down to a limit concentration because they are harmful to the product quality of ceramic. The content of the rare earth mineral is very slow $(0.04 \%)$, including of monazite, xenotime, parisite and colloidal rare earth. There is no radioactive minerals remained, indicating the re-source of the tailings is safe in ceramic application.

\subsubsection{Chemical Composition of Tailings by XRF}

The chemical composition of the tailings sample is presented in Table 2. As can be seen, the rich major chemical composition in oxides in mine tailing are $\mathrm{SiO}_{2}$ (78.32\%), $\mathrm{Al}_{2} \mathrm{O}_{3}(17.50 \%)$ and $\mathrm{Fe}_{2} \mathrm{O}_{3}(2.11 \%)$. Pure kaolinite $\left(\mathrm{Al}_{2} \mathrm{O}_{3} \cdot 2 \mathrm{SiO}_{2} \cdot 2 \mathrm{H}_{2} \mathrm{O}\right)$ is white in color and its chemical composition is $46.54 \% \mathrm{SiO}_{2}, 39.50 \% \mathrm{Al}_{2} \mathrm{O}_{3}$ and $13.96 \%$ $\mathrm{H}_{2} \mathrm{O}$ (Grimshaw, 1971) [7]. Assumed that all of $\mathrm{Al}_{2} \mathrm{O}_{3}$ (17.50\%) exist in kaolinite, it can be calculated that $44.3 \%$ of the tailings is kaolinite, which is similar to the results in Table 1 . It is deduced that most of $\mathrm{Al}_{2} \mathrm{O}_{3}$ exist in kaolinite. Hence, the content of kaolinite can be estimated by that of $\mathrm{Al}_{2} \mathrm{O}_{3}$ in this work.

Minor quantities of transition elements such as iron, titanium and manganese are generally present as ancillary minerals which adversely affect the optical properties of kaolins, especially, Fe-containing minerals (Chandrasekhar and Ramaswamy, 2006; Malengreau et al., 1996) [8] [9]. They cause brown-yellow colorations and reduce the whiteness. The Chinese national standard of kaolin (TC-3, GB/T 14563-2008) applied in ceramic industries requires that $\mathrm{Al}_{2} \mathrm{O}_{3} \geq 28 \%, \mathrm{Fe}_{2} \mathrm{O}_{3} \leq 1.8 \%, \mathrm{TiO}_{2} \leq 0.6 \%$ (mass ratio). Obviously, the $\mathrm{Fe}_{2} \mathrm{O}_{3}$ content is $2.11 \%$ is larger than the requirement, implying that iron removal is required before the utilization of the tailings. There is no further treatment to remove $\mathrm{TiO}_{2}$ in the separation of the tailings because the content of $\mathrm{TiO}_{2}$ is low.

The tailing is sieved by the standard sieves. The particle size distribution and the grade of $\mathrm{SiO}_{2}, \mathrm{Al}_{2} \mathrm{O}_{3}, \mathrm{Fe}_{2} \mathrm{O}_{3}$ 
Table 1. Mineral composition of the tailings.

\begin{tabular}{cccccc}
\hline Mineral & Content $\%$ & Mineral & Content $\%$ & Mineral & Content \% \\
\hline Kaolinite & 42.29 & Monazite & 0.01 & Colloidal rare earth & 0.01 \\
Quartz & 49.69 & Xenotime & 0.01 & Titanomagnetite & 1.10 \\
Feldspar & 3.90 & Parisite & 0.01 & Limonite & 0.29 \\
Diopside & 0.01 & Rutile & 0.09 & Ilmenite & 0.13 \\
Muscovite & 0.68 & Leucoxene & 0.10 & Iron sphene & 0.04 \\
Biotite & 1.36 & Pyrite & 0.01 & Remainder & 0.14 \\
Amphibole & 0.11 & Galena & 0.01 & Total & 100 \\
\hline
\end{tabular}

Table 2. Chemical composition of the tailings measured by XRF/\%.

\begin{tabular}{ccccccccc}
\hline $\mathrm{SiO}_{2}$ & $\mathrm{Al}_{2} \mathrm{O}_{3}$ & $\mathrm{Fe}_{2} \mathrm{O}_{3}$ & $\mathrm{TiO}_{2}$ & $\mathrm{~K}_{2} \mathrm{O}$ & $\mathrm{Na}_{2} \mathrm{O}$ & $\mathrm{CaO}$ & $\mathrm{MgO}$ \\
\hline 78.32 & 17.50 & 2.11 & 0.38 & 1.21 & 0.43 & 0.22 & 1.33 \\
\hline
\end{tabular}

and $\mathrm{TiO}_{2}$ in every distribution are listed in Table 3. As can be seen, the particle size of the tailing shows the bimodal distribution of $0.8 \mathrm{~mm}$ and $-0.043 \mathrm{~mm}$. The grade of $\mathrm{SiO}_{2}$ is larger than 91.46 for the $+0.4 \mathrm{~mm}$ fraction, implying that coarse grains are quartz and can be separated by $0.4 \mathrm{~mm}$ sieve. The grade of $\mathrm{SiO}_{2}$ decreases and the grade of $\mathrm{Al}_{2} \mathrm{O}_{3}$ increase with the decrease of the particle size. Hence, most of kaolinite exists in the -0.043 $\mathrm{mm}$ fraction. Kaolinite and quartz maybe separated by sieving. However, the iron content in the $-0.043 \mathrm{~mm}$ fraction is $2.16 \%$, implying that the iron-bearing minerals are mixed with kaolinite. Iron removal is required for the kaolinite separated from the tailings (Svoboda, J. and Fujita, T., 2003, Santos, et al. 2012, Chandrasekhar and Ramaswamy, 2007, Xia, et al. 2012, Zegeye, A. et al., 2013) [6] [10]-[13].

\subsection{Sorting Experiments in Laboratory Scale}

\subsubsection{Sorting of the Tailings by Shaker}

The tailing can be sorted by the shaker due to the difference of the density (the density of kaolinite is 1.58 - 1.63 $\mathrm{g} / \mathrm{cm}^{3}$; the density of quartz is $2.64-2.71 \mathrm{~g} / \mathrm{cm}^{3}$ ). Table 4 shows the sorting results of the tailings. Obviously, the heavy quartz remains in the underflow K1and the middling K2, whose gradation is over than $90 \%$. The abnormal data in underflow may be the results that some of kaolinites are entrained by quartz grains in large size. The gradation of $\mathrm{Al}_{2} \mathrm{O}_{3}$ increases with the decrease of the particle size of the tailing. It is worth mentioning that the gradation of $\mathrm{Al}_{2} \mathrm{O}_{3}$ is $24.46 \%$, which is far larger than the other zone. The yield of the tailings in overflow

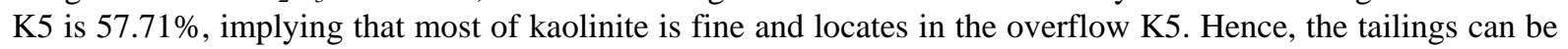
preliminarily separated into kaolinite and quartz by shaker. The gradation of $\mathrm{Fe}_{2} \mathrm{O}_{3}$ is $1.94 \%$ in the overflow, which is still higher than the national standard of TC-3. The recovery ratio of $\mathrm{Fe}_{2} \mathrm{O}_{3}$ in overflow is $69.90 \%$. Most of the fine Fe-bearing minerals are mixed with kaolinite. It is no use to remove iron by the shaker.

\subsubsection{Sorting of the Tailings by Settlement}

The gradation of $\mathrm{Al}_{2} \mathrm{O}_{3}$ in the overflow of the shaker is $24.46 \%$, which doesn't meet the requirement of TC-3 (in which, $\mathrm{Al}_{2} \mathrm{O}_{3} \geq 28 \%$ ). The tailings need to be sorted further.

Table 5 shows the sorting results of the tailings by settlement. The gradation of $\mathrm{Al}_{2} \mathrm{O}_{3}$ is larger than $28 \%$ if the particle size of the tailings is no more than $10 \mu \mathrm{m}$. Kaolinite required in ceramic industries can be separated from the rare earth tailing under the favorable sorting condition.

\subsubsection{Iron Removal}

It doesn't require separating kaolinite from quartz completely because they are both needed in traditional ceramic industries. Kaolinite and quartz share $91.98 \%$ of the ion-adsorption rare earth tailings (see Table 1). It implies that the tailing can be re-utilized in common ceramic industries if the $\mathrm{Fe}_{2} \mathrm{O}_{3}$ content can be decreased to $1.8 \%$. 
Table 3. Particle size distribution of the tailing and the quality of $\mathrm{SiO}_{2}, \mathrm{Al}_{2} \mathrm{O}_{3}, \mathrm{Fe}_{2} \mathrm{O}_{3}$ and $\mathrm{TiO}_{2}$.

\begin{tabular}{|c|c|c|c|c|c|c|c|c|c|}
\hline \multirow{2}{*}{ Particles size/mm } & \multirow{2}{*}{$\begin{array}{c}\text { Yield/ } \\
\%\end{array}$} & \multicolumn{4}{|c|}{ Gradation/\% } & \multicolumn{4}{|c|}{ Recovery ratio/\% } \\
\hline & & $\mathrm{SiO}_{2}$ & $\mathrm{Al}_{2} \mathrm{O}_{3}$ & $\mathrm{Fe}_{2} \mathrm{O}_{3}$ & $\mathrm{TiO}_{2}$ & $\mathrm{SiO}_{2}$ & $\mathrm{Al}_{2} \mathrm{O}_{3}$ & $\mathrm{Fe}_{2} \mathrm{O}_{3}$ & $\mathrm{TiO}_{2}$ \\
\hline 0.8 & 19.1 & 98.44 & 0.91 & 0.31 & 0.05 & 23.99 & 0.99 & 2.96 & 2.85 \\
\hline$-0.8-+0.4$ & 7.45 & 91.46 & 6.24 & 1.22 & 0.15 & 8.69 & 2.65 & 4.54 & 3.34 \\
\hline$-0.4-+0.25$ & 3.49 & 79.55 & 13.28 & 4.02 & 0.59 & 3.54 & 2.64 & 7.01 & 6.15 \\
\hline$-0.25-+0.12$ & 7.01 & 74.19 & 16.99 & 3.81 & 0.62 & 6.64 & 6.79 & 13.35 & 12.98 \\
\hline$-0.12-+0.075$ & 4.15 & 72.70 & 18.90 & 3.30 & 0.72 & 3.85 & 4.47 & 6.85 & 8.93 \\
\hline$-0.075-+0.043$ & 4.81 & 73.17 & 19.41 & 2.91 & 0.76 & 4.49 & 5.33 & 7.00 & 10.92 \\
\hline-0.043 & 53.99 & 70.84 & 25.04 & 2.16 & 0.34 & 48.80 & 77.12 & 58.29 & 54.83 \\
\hline$\sum$ (original ores) & 100 & 78.32 & 17.50 & 2.11 & 0.38 & 100 & 100 & 100 & 100 \\
\hline
\end{tabular}

Table 4. Sorting results of the tailings by shaker.

\begin{tabular}{|c|c|c|c|c|c|c|c|c|c|}
\hline \multirow{2}{*}{ Zone label } & \multirow{2}{*}{$\begin{array}{c}\text { Yield } \\
\text { /\% }\end{array}$} & \multicolumn{4}{|c|}{ Gradation/\% } & \multicolumn{4}{|c|}{ Recovery ratio/\% } \\
\hline & & $\mathrm{SiO}_{2}$ & $\mathrm{Al}_{2} \mathrm{O}_{3}$ & $\mathrm{Fe}_{2} \mathrm{O}_{3}$ & $\mathrm{TiO}_{2}$ & $\mathrm{SiO}_{2}$ & $\mathrm{Al}_{2} \mathrm{O}_{3}$ & $\mathrm{Fe}_{2} \mathrm{O}_{3}$ & $\mathrm{TiO}_{2}$ \\
\hline Underflow K1 & 0.67 & 86.42 & 6.74 & 4.21 & 0.76 & 0.74 & 0.27 & 1.79 & 2.00 \\
\hline Middling K2 & 21.47 & 92.32 & 5.03 & 1.36 & 0.25 & 24.91 & 6.32 & 18.23 & 20.82 \\
\hline Middling K3 & 17.88 & 89.30 & 8.52 & 0.73 & 0.14 & 20.06 & 8.91 & 8.15 & 9.71 \\
\hline Middling K4 & 2.26 & 82.28 & 14.39 & 1.37 & 0.29 & 2.34 & 1.90 & 1.93 & 2.54 \\
\hline Overflow K5 & 57.71 & 71.64 & 24.46 & 1.94 & 0.29 & 51.95 & 82.60 & 69.90 & 64.92 \\
\hline$\sum$ (original ores) & 100 & 78.32 & 17.50 & 2.11 & 0.38 & 100 & 100 & 100 & 100 \\
\hline
\end{tabular}

Table 5. Sorting results of the tailings by settlement.

\begin{tabular}{ccccc}
\hline \multirow{2}{*}{ Product label } & \multicolumn{3}{c}{ Gradation/\% } \\
\cline { 2 - 5 } & $\mathrm{SiO}_{2}$ & $\mathrm{Al}_{2} \mathrm{O}_{3}$ & $\mathrm{Fe}_{2} \mathrm{O}_{3}$ & $\mathrm{TiO}_{2}$ \\
\hline $5 \mu \mathrm{m}$ & 59.71 & 31.64 & 1.38 & 0.14 \\
$10 \mu \mathrm{m}$ & 64.32 & 28.09 & 1.54 & 0.18 \\
$20 \mu \mathrm{m}$ & 65.61 & 24.47 & 2.5 & 0.41 \\
Overflow in shaker & 71.64 & 24.46 & 1.94 & 0.29 \\
\hline
\end{tabular}

Table 6 shows the distribution of Fe element in the tailings. Fe element distributes mostly in titanomagnetite, kaolinite and limonite. The magnetic titanomagnetite and limonite can be removed by a magnetic separator. If it is done, the total $\mathrm{Fe}$ content in the tailing can be reduced to $1.23 \%$, which meets the requirement of the standard of TC-3 in ceramic application. The effect of the magnetic induction on the Fe content is listed in Table 7.

As can be seen, the Fe gradation of the sorted tailing decreases with the increase of the magnetic field intensity. However, the ratio of iron removal is not proportional to the magnetic induction. The ratio of iron removal increases sharply with the magnetic field intensity. When the magnetic field intensity is $0.6 \mathrm{~T}$, the Fe gradation of the sorted tailing is $1.06 \%$ and the ratio of iron removal is $50.41 \%$. Under this condition, most of titanomagnetite and limonite is removed. However, the ratio of iron removal increases slightly (4.68\%) when the magnetic induction increases further from $0.6 \mathrm{~T}$ to $1 \mathrm{~T}$. Therefore, the economical magnetic field intensity is $0.6 \mathrm{~T}$.

\subsection{Separation Experiments in Pilot Scale}

It has been proved that the tailing can be sorted by gravity method in laboratory scale. To make the tailing more profitable, kaolinite was separated from the tailing. The tailing slurry was firstly sieved by a high frequency vi- 
Table 6. Distribution of Fe element in the tailings.

\begin{tabular}{ccccc}
\hline Mineral & Content of mineral/\% & $\mathrm{Fe}_{2} \mathrm{O}_{3}$ content in mineral/\% ${ }^{*} \mathrm{Fe}_{2} \mathrm{O}_{3}$ distribution in tailing/\% & $\begin{array}{c}\mathrm{Ratio} \mathrm{of}_{\mathrm{Fe}_{2} \mathrm{O}_{3}} \\
\text { distribution/\% }\end{array}$ \\
\hline Kaolinite & 42.29 & 0.57 & 0.24 & 16.99 \\
Quartz & 49.69 & 0.17 & 0.08 & 5.98 \\
Feldspar & 3.90 & 0.16 & 0.01 & 0.43 \\
Titanomagnetite & 1.10 & 66.28 & 0.73 & 51.73 \\
Limonite & 0.29 & 53.19 & 0.15 & 10.85 \\
Ilmenite & 0.13 & 32.07 & 0.04 & 2.98 \\
Muscovite & 0.68 & 2.24 & 0.02 & 1.08 \\
Biotite & 1.36 & 10.34 & 0.14 & 9.98 \\
Total & 99.44 & - & 1.41 & 100 \\
\hline
\end{tabular}

Notes: "the average value measured by MLA, which is smaller than by XRF due to the crystal water.

Table 7. Effect of the magnetic field intensity on the iron removal.

\begin{tabular}{ccc}
\hline \multirow{2}{*}{ Magnetic field intensity/T } & \multicolumn{2}{c}{$\mathrm{Fe}_{2} \mathrm{O}_{3}$} \\
\cline { 2 - 3 } & Gradation/\% & Ratio of iron removal/\% \\
\hline 0.2 & 1.40 & 34.78 \\
0.6 & 1.26 & 41.02 \\
0.8 & 1.06 & 50.41 \\
1 & 0.99 & 53.80 \\
Tailing & 0.96 & 55.09 \\
\hline
\end{tabular}

brating sieve (GYX11-1210, sieve size is $0.4 \mathrm{~mm}$ ). The coarse quartz was removed. The $-0.44 \mathrm{~mm}$ fraction of the slurry was delivered into a spiral chute (TGL 0610). Table 8 shows the separation results of the spiral chute.

As can be seen, the gradations of $\mathrm{SiO}_{2}$ in $\mathrm{Ks} 1$ and $\mathrm{Ks} 2$ area are higher than the other areas, indicating that quartz can be sorted further by the spiral chute after removal of the coarse quartz. However, the fine quartz is also mixed with kaolinite because the recovery ratio of $\mathrm{SiO}_{2}$ in $\mathrm{Ks} 5$ area is $43.40 \%$. Correspondingly, kaolinite distributes mainly in Ks4 and Ks5 area, whose gradation is about 24\% and total recovery ratio is $76.56 \%$. The $\mathrm{Al}_{2} \mathrm{O}_{3}$ gradation still doesn't meet the standard of TC-3 due to the mixing of fine quartz.

To separate kaolinite from quartz further, the K4 and K5 fractions of the slurry were delivered into the hydrocyclone. The separation result is shown in Table 9.

It can be seen that the sorting by the hydrocyclone contributes to separation of kaolinite. However, the aim of the separation is still not obtained. The tailing in overflow needs to be separated second time. Table 10 gives the separation results of the hydrocyclone secondly.

Table 10 shows that the gradation of $\mathrm{Al}_{2} \mathrm{O}_{3}$ in the overflow is $28.6 \%$. The sorted kaolinite can be applied in ceramic industries. Correspondingly, the yield of the overflow is $87.13 \%$, implying that the separation by hydrocyclone secondly has the interesting in the point of economical view. The results in pilot scale agree with those in laboratory scale.

The whiteness is one of the most important factors in determining the application and economic value of kaolinite (Xia, et al. 2012) [12]. In general, the most deleterious impurities for whiteness of kaolin are iron oxide and titanium oxide minerals. Iron removal is required based on the results in Table $\mathbf{1 0}$ and the national standard of China (TC-3).

Iron removal of the tailing in overflow Kh2 is processed in high gradient magnetic separator (SSS-I-800). Table 11 gives the separation results of the magnetic separator. 
Table 8. Separation results of spiral chute.

\begin{tabular}{|c|c|c|c|c|c|c|c|c|c|}
\hline \multirow{2}{*}{ Production label } & \multirow{2}{*}{$\begin{array}{c}\text { Yield/ } \\
\%\end{array}$} & \multicolumn{4}{|c|}{ Gradation/\% } & \multicolumn{4}{|c|}{ Recovery ratio/\% } \\
\hline & & $\mathrm{SiO}_{2}$ & $\mathrm{Al}_{2} \mathrm{O}_{3}$ & $\mathrm{Fe}_{2} \mathrm{O}_{3}$ & $\mathrm{TiO}_{2}$ & $\mathrm{SiO}_{2}$ & $\mathrm{Al}_{2} \mathrm{O}_{3}$ & $\mathrm{Fe}_{2} \mathrm{O}_{3}$ & $\mathrm{TiO}_{2}$ \\
\hline Underflow Ks1 & 16.78 & 89.13 & 7.54 & 3.13 & 0.61 & 19.19 & 5.91 & 23.81 & 26.06 \\
\hline Middling Ks2 & 10.12 & 86.57 & 10.52 & 1.00 & 0.27 & 11.25 & 5.74 & 4.59 & 6.96 \\
\hline Middling Ks3 & 12.03 & 78.76 & 18.19 & 1.19 & 0.27 & 12.17 & 11.79 & 6.49 & 8.27 \\
\hline Middling Ks4 & 15.07 & 72.29 & 24.00 & 2.50 & 0.40 & 13.99 & 19.49 & 17.09 & 15.35 \\
\hline Overflow Ks5 & 46.01 & 73.46 & 23.02 & 2.30 & 0.37 & 43.40 & 57.07 & 48.01 & 43.36 \\
\hline
\end{tabular}

Table 9. Separation results of hydrocyclone (first time).

\begin{tabular}{cccccccccccc}
\hline & \multirow{2}{*}{$\begin{array}{c}\text { Yield } \\
\text { Product label }\end{array}$} & \multicolumn{4}{c}{ Gradation/\% } \\
\cline { 3 - 11 } & & $\mathrm{SiO}_{2}$ & $\mathrm{Al}_{2} \mathrm{O}_{3}$ & $\mathrm{Fe}_{2} \mathrm{O}_{3}$ & $\mathrm{TiO}_{2}$ & $\mathrm{SiO}_{2}$ & $\mathrm{Al}_{2} \mathrm{O}_{3}$ & $\mathrm{Fe}_{2} \mathrm{O}_{3}$ & $\mathrm{TiO}_{2}$ \\
\hline Underflow Kh1 & 30.75 & 72.17 & 24.66 & 2.45 & 0.42 & 31.48 & 29.35 & 27.63 & 37.56 \\
Overflow Kh2 & 69.25 & 70.93 & 26.36 & 2.85 & 0.31 & 68.52 & 70.65 & 72.37 & 62.44 \\
$\sum$ (original tailing) & 100 & 73.17 & 23.26 & 1.87 & 0.29 & 100 & 100 & 100 & 100 \\
\hline
\end{tabular}

Table 10. Separation results of hydrocyclone (second time).

\begin{tabular}{|c|c|c|c|c|c|c|c|c|c|}
\hline \multirow{2}{*}{ Product label } & \multirow{2}{*}{$\begin{array}{c}\text { Yield/ } \\
\%\end{array}$} & \multicolumn{4}{|c|}{ Gradation/\% } & \multicolumn{4}{|c|}{ Recovery ratio/\% } \\
\hline & & $\mathrm{SiO}_{2}$ & $\mathrm{Al}_{2} \mathrm{O}_{3}$ & $\mathrm{Fe}_{2} \mathrm{O}_{3}$ & $\mathrm{TiO}_{2}$ & $\mathrm{SiO}_{2}$ & $\mathrm{Al}_{2} \mathrm{O}_{3}$ & $\mathrm{Fe}_{2} \mathrm{O}_{3}$ & $\mathrm{TiO}_{2}$ \\
\hline Underflow Kh1 & 12.87 & 72.46 & 24.95 & 2.66 & 0.33 & 13.66 & 11.41 & 11.82 & 13.59 \\
\hline Overflow Kh2 & 87.13 & 68.63 & 28.60 & 2.93 & 0.31 & 86.34 & 88.59 & 88.18 & 86.41 \\
\hline$\sum$ (original tailing) & 100 & 70.93 & 26.36 & 2.85 & 0.31 & 100 & 100 & 100 & 100 \\
\hline
\end{tabular}

Table 11. Separation results of the high gradient magnetic separator.

\begin{tabular}{|c|c|c|c|c|c|c|c|c|c|}
\hline \multirow{2}{*}{ Product } & \multirow{2}{*}{$\begin{array}{c}\text { Yield/ } \\
\%\end{array}$} & \multicolumn{4}{|c|}{ Gradation/\% } & \multicolumn{4}{|c|}{ Recovery ratio/\% } \\
\hline & & $\mathrm{SiO}_{2}$ & $\mathrm{Al}_{2} \mathrm{O}_{3}$ & $\mathrm{Fe}_{2} \mathrm{O}_{3}$ & $\mathrm{TiO}_{2}$ & $\mathrm{SiO}_{2}$ & $\mathrm{Al}_{2} \mathrm{O}_{3}$ & $\mathrm{Fe}_{2} \mathrm{O}_{3}$ & $\mathrm{TiO}_{2}$ \\
\hline Magnetic mineral & 18.52 & 68.38 & 19.29 & 10.53 & 0.87 & 18.70 & 12.97 & 66.42 & 51.00 \\
\hline Diamagnetic mineral & 81.48 & 67.57 & 29.43 & 1.21 & 0.19 & 81.30 & 87.03 & 33.58 & 49.00 \\
\hline$\sum$ (original tailing) & 100 & 68.63 & 28.60 & 2.93 & 0.31 & 100 & 100 & 100 & 100 \\
\hline
\end{tabular}

The results in Table 11 show that $66.42 \%$ of $\mathrm{Fe}_{2} \mathrm{O}_{3}$ can be removed by the magnetic separator. Comparing to the results in Table 6 , all the magnetic titanomagnetite and limonite have been removed by the magnetic separator. The magnetic separator in pilot scale has the same separation action with that in laboratory scale. The $\mathrm{Fe}_{2} \mathrm{O}_{3}$ content decreases from $2.93 \%$ to $1.21 \%$, which is less that the requirement of TC-3 (1.8\%). Obviously, the $\mathrm{Fe}_{2} \mathrm{O}_{3}$ that exists in diamagnetic minerals must be removed by chemical method if the quality of kaolinite needs to be increased further (Svoboda, and Fujita, 2003, Santos, et al. 2012, Chandrasekhar and Ramaswamy, 2007, Xia, et al. 2012, Zegeye, et al., 2013) [6] [10]-[13].

In a word, after the above-mentioned separation processes, 30.2\% of the ion-adsorption rare earth tailing can be re-sourced and applied in ceramic industries [The total yield is estimated by the yields in every separation process: $(46.01+15.07) \% \times 69.25 \% \times 87.13 \% \times 81.84 \%=30.2 \%]$. The recovery ratio of kaolinite is $41.7 \%$, which is estimated as the yield. Some of kaolinite cannot be sorted because it is mixed or accompanied by the other minerals. The recovery ratio of kaolinite may be increased by crushing the tailing. However, it is not eco- 
nomic considering most of the coarse grains in the tailing are quartz.

\section{Conclusions}

Kaolinite had been sorted from ion-adsorption rare earth tailings in Southern China in laboratory scale and pilot scale. The conclusions can be drawn as following:

1) The ion-adsorption rare earth tailing in Southern China is mainly compose of kaolinite and quartz, which can be re-sourced because no radioactive minerals exist.

2) Coarse quartz and fine kaolinite can be separated by sieves, shaker, spiral chute or hydrocyclone. There are the similar results in laboratory scale and in pilot scale. $30.2 \%$ of the tailings can be re-sourced and applied in ceramic industries.

3) $41.7 \%$ of kaolinite can be obtained after sorting and iron removal by magnetic separator in pilot scale, which meet the national standard of China (TC-3). $\mathrm{Fe}_{2} \mathrm{O}_{3}$ in the sorted kaolinite has the gradation of $1.21 \%$, which should to be removed by chemical method if the quality of kaolinite needs to increase further.

\section{Acknowledgements}

The authors gratefully acknowledge the financial support provided by the National High-tech Research and Development Program of China (Grant No. 2012AA061903) and the National Natural Science Foundation of China (No. 51262013, 51362015).

\section{References}

[1] Su, W. (2009) Economic and Policy Analysis of China’s Rare Earth Industry (in Chinese). China Financial and Economic Publishing House, Beijing.

[2] Chen, Z. (2011) Global Rare Earth Resources and Scenarios of Future Rare Earth Industry. Journal of Rare Earths, 29, 1-6. http://dx.doi.org/10.1016/S1002-0721(10)60401-2

[3] Yang, X. (2013) China’s Ion-Adsorption Rare Earth Resources, Mining Consequences and Preservation. Environmental Development, 8, 131-136. http://dx.doi.org/10.1016/j.envdev.2013.03.006

[4] Wübbeke, J. (2013) Rare Earth Elements in China: Policies and Narratives of Reinventing an Industry. Resources Policy, 38, 384-394. http://dx.doi.org/10.1016/j.resourpol.2013.05.005

[5] Chen, L. (2011) Effect of Magnetic Field Orientation on High Gradient Magnetic Separation Performance. Minerals Engineering, 24, 88-90. http://dx.doi.org/10.1016/j.mineng.2010.09.019

[6] Svoboda, J. and Fujita, T. (2003) Recent Developments in Magnetic Methods of Material Separation. Minerals Engineering, 16, 785-792. http://dx.doi.org/10.1016/S0892-6875(03)00212-7

[7] Grimshaw, R.W. (1971) Physics and Chemistry of Clay. 4th Edition, Ernest Benn, London.

[8] Chandrasekhar, S. and Ramaswamy, S. (2006) Iron Minerals and Their Influence on the Optical Properties of Two Indian Kaolins. Applied Clay Science, 33, 269-277. http://dx.doi.org/10.1016/j.clay.2006.06.008

[9] Malengreau, N., Bedidi, A., Muller, J.P. and Herbillions, A.J. (1996) Spectroscopic Control of Iron Oxide Dissolution in Two Ferralitic Soils. European Journal of Soil Science, 47, 13-20. http://dx.doi.org/10.1111/j.1365-2389.1996.tb01367.x

[10] Santos, E., Scorzelli, R.B., Bertolino, L.C., Alves, O.C. and Munayco, P. (2012) Characterization of Kaolin from the Capim River Region-Brazil. Applied Clay Science, 55, 164-167. http://dx.doi.org/10.1016/j.clay.2011.11.009

[11] Chandrasekhar, S. and Ramaswamy, S. (2007) Investigation on a Gray Kaolin from South East India. Applied Clay Science, 37, 32-46. http://dx.doi.org/10.1016/j.clay.2006.11.007

[12] Xia, G., Lu M, Su, X. and Zhao, X. (2012) Iron Removal from Kaolin Using Thiourea Assisted by Ultrasonic Wave. Ultrasonics Sonochemistry, 19, 38-42. http://dx.doi.org/10.1016/j.ultsonch.2011.05.008

[13] Zegeye, A., Yahaya, S., Fialips, C.I., White, M.L., Gray, N.D. and Manning, D.A.C. (2013) Refinement of Industrial Kaolin by Microbial Removal of Iron-Bearing Impurities. Applied Clay Science, 86, 47-53.

http://dx.doi.org/10.1016/j.clay.2013.08.041 